\title{
VANCOMYCIN-RESISTANT ENTEROCOCCUS FAECIUM COLONIZATION AND CLOSTRIDIUM DIFFICILE INFECTION IN A HEMATOLOGIC PATIENT
}

\author{
Ivana Goić-Barišici ${ }^{1,2}$, Marina Radić1,2, Anita $\operatorname{Novak}^{1,2}, \check{Z}_{\text {ana }}$ Rubić ${ }^{1,2}$, \\ Nataša Boban ${ }^{2,3}$, Boris Lukšićc, and Marija Tonkić ${ }^{1,2}$ \\ ${ }^{1}$ Department of Clinical Microbiology, Split University Hospital Centre, Split, Croatia; \\ ${ }^{2}$ University of Split School of Medicine, Split, Croatia; \\ ${ }^{3}$ Department of Clinical Epidemiology, Split University Hospital Centre, Split, Croatia; \\ ${ }^{4}$ Department of Infectious Diseases, Split University Hospital Centre, Split, Croatia
}

\begin{abstract}
SUMMARY - Vancomycin-resistant enterococci (VRE), especially Enterococcus faecium, have emerged as significant nosocomial pathogens and patients with impaired host defenses are at a particular risk of VRE infection. The most common occurrence is asymptomatic colonization of the gastrointestinal tract that can persist for a long time and serve as a reservoir for transmission of VRE to other patients. We present a case of a patient who was diagnosed with acute myelogenous leukemia and suffered from bone marrow aplasia following induction therapy. The patient received prolonged broad-spectrum antimicrobial therapy. During hospital stay, the patient developed Clostridium difficile infection (CDI) and was found to be colonized with a strain of Enterococcus faecium resistant to vancomycin during therapy for CDI. This case also highlights the role of risk factors that could contribute to development of resistance, particularly CDI. Early detection of VRE colonization or infection is a crucial component in hospital program designed to prevent transmission of nosocomial infections. Surveillance cultures of such patients should be mandatory.
\end{abstract}

Key words: Acute myelogenous leukemia; Clostridium difficile; Enterococcus faecium; Vancomycin-resistant enterococcus

\section{Introduction}

Enterococci resistant to vancomycin have emerged as the leading cause of nosocomial infections worldwide. In an effort to prevent the spread of vancomycin resistance, Centers for Disease Control and Prevention have recommended periodical culture surveys of stool and rectal swabs, depending on the risk population and hospital units involved ${ }^{1}$. Therefore, this screening has been found to be effective in detecting vancomycin-resistant enterococci (VRE) $)^{2,3}$. However,

Correspondence to: Marina Radic, MD, Department of Clinical Microbiology, Split University Hospital Centre, Spinčićeva 1, HR21000 Split, Croatia

E-mail: radicmarina14@googlemail.com

Received November 9,2015, accepted September 20, 2016 the widespread use of glycopeptides in hospitals has led to the emergence of VRE, which account for approximately $30 \%$ of all enterococcal infections, with the majority of VRE isolates ( $>90 \%)$ being Enterococcus (E.) faecium ${ }^{4}$. Some investigators have reported the overall prevalence of VRE in Europe to range from $1.5 \%$ to $8.6 \% \%^{5,6}$. In the United States, the prevalence of VRE on admission to an intensive care unit has been reported to range from $12 \%$ to $43 \%{ }^{7}$. The reported rates of VRE colonization in hospitalized patients vary, ranging from $1.5 \%$ to $32 \%, 5,6$. The risk factors for nosocomial VRE colonization or infection include advanced age, prolonged hospital stay, interhospital transfer, prolonged duration of antibiotic treatment (especially with vancomycin and cephalosporins), different surgical procedures and presence of immuno- 
compromised state ${ }^{9,10}$. Patients with Clostridium diffcile infection (CDI) are considered to be at a greater risk of becoming colonized with VRE, probably because of the common risk factors involved ${ }^{11}$. CDI is also common in hematologic patients, with the incidence rate ranging from $4.8 \%$ to $9 \%$ in patients with acute myelogenous leukemia, from $4.9 \%$ to $7.5 \%$ in patients undergoing autologous and from $14 \%$ to $30.4 \%$ in those undergoing allogeneic hematopoietic stem cell transplantation (HSCT) ${ }^{12-15}$.

This report presents a case of a patient with acute myelogenous leukemia following induction therapy, whose surveillance rectal and throat swabs yielded $E$. faecium resistant to vancomycin, $\operatorname{Van} A$ phenotype.

\section{Case Report}

In March 2015, a 48-year-old female patient was admitted for the first time to the Department of Hematology because of fever and spontaneous gingival bleeding. During the previous year, she was taking antibiotic treatment several times due to recurrent urinary tract infection (UTI). Two weeks before this admission, she was treated with peroral cefuroxime because of suspected pyelonephritis. After finishing the antibiotic treatment prescribed, laboratory findings showed leukocytosis $\left(39.3 \times 10^{9} / \mathrm{L}\right)$ and trombocytopenia $\left(82 \times 10^{9} / \mathrm{L}\right)$ with blasts detected in peripheral blood $(17 \%)$, so she was hospitalized for further treatment.

On day 2 of her hospital stay, urine culture yielded Klebsiella pneumoniae $>10^{5}$ colony forming units (CFU/ $\mathrm{mL}$ ), with a significantly lowered leukocyte count after treatment for UTI. However, further clinical findings revealed acute myelogenous leukemia, with no chromosome 16 inversion detected by fluorescent in situ hybridization technique. Following induction therapy, the patient suffered from bone marrow aplasia accompanied by febrility and increase in $\mathrm{C}$-reactive protein level $(256.7 \mathrm{mg} / \mathrm{L})$. Due to development of fever in granulocytopenia, and based on the clinical picture, duration and degree of granulocytopenia, monotherapy with a beta-lactam with activity against Pseudomonas aeruginosa was first started, combined with other gramnegative and gram-positive agents, for suspicion of possible infection caused by resistant gram-negative or gram-positive bacteria. Therefore, further therapy included piperacillin/tazobactam $(3 \times 4.5 \mathrm{~g}$ i.v. daily for 4 days), meropenem ( $3 \times 1 \mathrm{~g}$ i.v. daily for 17 days), then amikacin ( $2 \times 500 \mathrm{mg}$ i.v. daily for 8 days), vancomycin ( $2 \mathrm{x} 1 \mathrm{~g}$ i.v. daily for 10 days) and imipenem ( $3 \mathrm{x} 1 \mathrm{~g}$ i.v. daily for 10 days). As our patient was at a high risk of developing fungal infection, empirical antifungal therapy with amphotericin $\mathrm{B}$ was also administered. The patient became afebrile from day 30 . After 40 days of hospital stay, the patient was discharged with no prophylactic antibiotic therapy.

One week after discharge, in April, the patient was readmitted to the Department of Hematology for further chemotherapy. From that time on, she was clinically stable, afebrile, with periods of bone marrow aplasia, so multiple transfusions of red blood cells and platelets were administered. On day 7 , she started having profuse watery diarrhea, up to 10 times, which was clinically indicative of Clostridium (C.) difficile infection, and a stool sample was taken and sent for detection of $C$. difficile toxin. On the same day, after C. difficile toxin was detected, peroral treatment with vancomycin was initiated at a dose of $2.5 \mathrm{~mL} 4$ times a day for 10 days.

The patient had negative surveillance cultures upon admission (initial screening). However, in order to exclude possible colonization with multidrug-resistant hospital pathogens, surveillance cultures should be taken on at least three consecutive occasions, one week or more apart ${ }^{16}$. Therefore, another surveillance throat swab was obtained on day 10 and yielded $E$. faecium resistant to vancomycin. On day 15 of admission, she became febrile $\left(38.4{ }^{\circ} \mathrm{C}\right)$, so blood culture was taken and Klebsiella pneumoniae was grown. At that time, meropenem was added to therapy at a dose of $1 \mathrm{~g}$ i.v. every 8 hours. Surveillance rectal swab was taken on day 19 for detection of multidrug-resistant hospital pathogens (vancomycin-resistant enterococci, VRE; multidrug-resistant Acinetobacter baumannii, MRAB; carbapenem-resistant Enterobacteriaceae, CRE; extended spectrum beta-lactamase producing gram-negative bacilli, ESBL) and E. faecium resistant to vancomycin was isolated.

The strain was sent to Dr Fran Mihaljević University Hospital for Infectious Diseases in Zagreb, and polymerase chain reaction (PCR) assay confirmed the $\operatorname{Van} A$ phenotype of vancomycin resistance.

\section{Microbiology}

Rectal swab was inoculated on CHROMagar VRE plate, a chromogenic medium for detection of $\mathrm{VanAl}$ 
VanB phenotype of vancomycin resistance in Enterococci (CHROMagar, Paris, France). On the first day of subculture at $37^{\circ} \mathrm{C}$, pink to mauve colonies were revealed (after $24 \mathrm{~h}$ ). The grown isolate was confirmed as E. faecium using automated Vitek 2 System (bioMerieux, Marcy-l'Etoile, France).

Throat swab was inoculated on blood agar and shiny, $\gamma$ (gamma)-hemolytic colonies were observed after 24 hours of incubation with further identification being identical as described above.

Antimicrobial susceptibility testing was first done using Kirby-Bauer disk-diffusion method and confirmed by determining minimum inhibitory concentration (MIC) values using Vitek 2 automated method. The strain was shown to be resistant to ampicillin $(\mathrm{MIC} \geq 32 \mu \mathrm{g} / \mathrm{mL}$ ), vancomycin ( $\mathrm{MIC} \geq 32 \mu \mathrm{g} / \mathrm{mL}$ ) and teicoplanin (MIC $\geq 32 \mu \mathrm{g} / \mathrm{mL}$ ), but susceptible to linezolid (MIC $2 \mu \mathrm{g} / \mathrm{mL}$ ) and tigecycline (MIC $\leq 0.12$ $\mu \mathrm{g} / \mathrm{mL}$ ), having a $\operatorname{VanA}$ specific phenotype of vancomycin resistance confirmed by PCR assay.

Stool sample was tested according to two-step algorithm guidelines of the European Society of Clinical Microbiology and Infectious Disease and a toxigenic strain of C. difficile was detected using a confirmatory molecular test ${ }^{17}$.

\section{Discussion}

Enterococci resistant to vancomycin were first detected in England in $1988^{18}$. VRE, especially E. faecium, is a significant nosocomial pathogen and presents a serious threat to immunocompromised patients. Compared to strains of E. faecalis, E. faecium displays a higher degree of resistance to multiple antibiotics, including ampicillin, gentamicin, ciprofloxacin, vancomycin and teicoplanin ${ }^{19}$. Therefore, it is important to identify the enterococcal strain to the species level. Enterococci belong to the fourth most common nosocomial pathogens in intensive care units, with VRE accounting for $28.5 \%$ of enterococcal isolates ${ }^{20}$. Invasive VRE infections have been associated with high morbidity and mortality rates ${ }^{21,22}$. Studies found crude mortality rates to range from $17 \%$ to $100 \%$, with a mortality rate of $73 \%$ in patients with hematologic malignancies ${ }^{23-25}$. There are studies showing VRE infection to be a strong predictor of mortality in liver transplant patients, with a mortality rate of $46 \%$ in liver transplant recipients with VRE bacteremia ${ }^{26,27}$. It has been suggested that VRE infections and colonization may be a reflection of a complicated medical course, and those patients have therefore been at a higher risk of dying, which could contribute to high mortality rates. Asymptomatic VRE colonization is of particular interest as it can persist for a long period and serve as a reservoir for transmission of VRE or present a source of possible infection. Thus, it is important to perform active surveillance (screening) of patients, especially those in intensive care units and hemato-oncology wards ${ }^{9,10}$. Many studies also showed correlation between VRE colonization and treatment with certain antimicrobial agents such as metronidazole, secondand third-generation cephalosporins, aminoglycosides and vancomycin ${ }^{28,29}$.

In our case, the patient was on a prolonged broadspectrum antimicrobial therapy during her first hospitalization (meropenem, piperacillin/tazobactam, then amikacin, vancomycin and imipenem/cilastatin), which was continued with meropenem and vancomycin during second hospitalization. She was also immunosuppressed because of her hematologic disease, which has been identified as an independent risk factor for acquiring $\mathrm{VRE}^{30}$. Developing diarrhea in our patient could have also increased the likelihood of colonization with VRE, as proposed in a study by Falk et al. ${ }^{31}$. Prolonged hospital stay could have also contributed in our case. Due to bone marrow aplasia, she was isolated in a hematologic sterile unit. All the risk factors mentioned could have triggered the development of resistance, especially prolonged therapy with vancomycin, which is more likely to promote colonization and transmission of VRE by selection pressure. As the $E$. faecium strain resistant to vancomycin was isolated from surveillance throat and rectal swabs, with no clinical and laboratory markers of infection, we detected gastrointestinal VRE colonization. Most VRE colonized patients remain colonized for a long period. Montecalvo et al. showed a 7-week persistence of gastrointestinal VRE colonization in adult patients hospitalized on oncology ward ${ }^{32}$.

There are studies that indicate a correlation between $C$. difficile infection and gastrointestinal VRE colonization, possibly because of the common risk factors including prolonged broad-spectrum antimicrobial therapy, extended hospital stay and underlying immunocompromised state ${ }^{10}$. In this way, $C$. difficile infection could be a possible predictor for developing 
VRE associated infection or colonization due to similar patient risk profile 33,34 . Our patient had both $C$. difficile infection and VRE colonization, which could be explained by the risk factors mentioned above.

Results of some studies indicate the possibility of VRE screening by using stools sent for $C$. difficile toxin analysis, as the results are comparable to screening using separately taken stool specimens or rectal swabs ${ }^{11,35}$. This is also less invasive and might be less of a problem in neutropenic patients for whom rectal swabs are sometimes a concern ${ }^{35}$. However, all these promising results could potentially lead to in-hospital screening using stools sent for $C$. difficile toxin analysis as a reasonable surrogate for screening individual high-risk patients, with substantial cost savings ${ }^{35}$.

Although up to now six phenotypes of vancomycin resistance have been described in enterococci, the $\operatorname{Van} A$ and $\operatorname{Van} B$ phenotypes are clinically significant and mediated by transferable operons. The VanA phenotype is almost always plasmid-mediated, raising the possibility of horizontal transfer of resistance ${ }^{36}$.

By using measures of active screening of patients, we successfully detected VRE $\operatorname{Van} A$ phenotype in our institution, emphasizing their importance and continuous implementation, especially in high-risk patients. According to the last available data provided by the Croatian Committee for Antibiotic Resistance Surveillance in 2013 on the three-month follow-up (October 1 to December 31), 5\% of E. faecium strains resistant to vancomycin were isolated ${ }^{37}$.

Performing special surveillance cultures of patients to detect gastrointestinal colonization should be considered as an essential component of successful VRE control programs. Obtaining periodic stool or rectal specimens from high-risk patients such as those in intensive care units, hematology-oncology wards or transplantation units should be mandatory. Surveillance cultures should be taken upon admission and twice weekly thereafter, and should be inoculated on appropriate selective media for detecting $\mathrm{VRE}^{16,38}$.

In conclusion, early detection of VRE colonization or infection is a crucial component of hospital program designed to prevent nosocomial infections. Quick information from microbiology laboratory is the first line of defense against the intrahospital spread of VRE. Prompt and correct identification of enterococci and detection of vancomycin resistance are essential in detection of VRE colonization or infection, in order to avoid complex and costly procedures required when the problem is delayed.

Active screening accompanied by infection control measures is crucial in the prevention of VRE transmission. Rational use of antibiotics is also a helpful preventive measure against the development of antimicrobial resistance.

\section{Acknowledgments}

We are thankful to Dr. Dominik Lozic from the Department of Hematology, Split University Hospital Centre, for his contribution in providing patient data. We also thank Dr. Iva Butić from the Department of Clinical Microbiology, Dr Fran Mihaljević University Hospital for Infectious Diseases, Zagreb, for her generous assistance in molecular confirmation of the resistance phenotype.

\section{References}

1. Hospital Infection Control Practices Advisory Committee (HICPAC). Recommendations for preventing the spread of vancomycin resistance. Infect Control Hosp Epidemiol. 1995; 16:105-13. Erratum in: Infect Control Hosp Epidemiol. 1995; 16:498, http://dx.doi.org/10.1086/647066

2. Christiansen KJ, Tibbett PA, Beresford W, Pearman JW, Lee RC, Coombs GW, et al. Eradication of a large outbreak of a single strain of vanB vancomycin-resistant Enterococcus faecium at a major Australian teaching hospital. Infect Control Hosp Epidemiol.2004;25:384-90,http://dx.doi.org/10.1086/502410

3. Nourse C, Byrne C, Murphy H, Kaufmann ME, Clarke A, Butler K. Eradication of vancomycin-resistant Enterococcus faecium from a paediatric oncology unit and prevalence of colonization in hospitalized and community-based children. Epidemiol Infect. 2000;124:53-9, http://dx.doi.org/10.1017/s09502 $6889900326 \mathrm{x}$

4. Deshpande LM, Fritsche TR, Moet GJ, Biedenbach DJ, Jones RN. Antimicrobial resistance and molecular epidemiology of vancomycin-resistant enterococci from North America and Europe: a report from the SENTRY antimicrobial surveillance program. Diagn Microbiol Infect Dis. 2007;58:163-70, http:// dx.doi.org/10.1016/j.diagnmicrobio.2006.12.022

5. Gambarotto K, Ploy MC, Turlure P, Grélaud C, Martin C, Bordessoule $\mathrm{D}$, et al. Prevalence of vancomycin-resistant enterococci in fecal samples from hospitalized patients and nonhospitalized controls in a cattle-rearing area of France. J Clin Microbiol. 2000;38:620-4, http://dx.doi.org/10.1128/JCM.38. 2.620-624.2000

6. Van den Braak N, Ott A, van Belkum A, Kluytmans JA, Koeleman JG, Spanjaard L, et al. Prevalence and determinants of fecal colonization with vancomycin-resistant Enterococcus in 
hospitalized patients in The Netherlands. Infect Control Hosp Epidemiol. 2000;21:520-4, http://dx.doi.org/10.1086/501797

7. Warren DK, Kollef MH, Seiler SM, Fridkin SK, Fraser VJ. The epidemiology of vancomycin-resistant Enterococcus colonization in a medical intensive care unit. Infect Control Hosp Epidemiol. 2003;24:257-63, http://dx.doi.org/10.1086/502199

8. Matar MJ, Tarrand J, Raad I, Rolston KV. Colonization and infection with vancomycin-resistant Enterococcus among patients with cancer. Am J Infect Control. 2006;34:534-6, http:// dx.doi.org/10.1016/j.ajic.2006.04.205

9. Chavers LS, Moser SA, Benjamin WH, Banks SE, Steinhauer JR, Smith AM, et al. Vancomycin-resistant enterococci: 15 years and counting. J Hosp Infect. 2003;53:159-71, http://dx. doi.org/10.1053/jhin.2002.1357

10. Safdar N, Maki DG. The commonality of risk factors for nosocomial colonization and infection with antimicrobial-resistant Staphylococcus aureus, enterococcus, gram-negative bacilli, Clostridium difficile, and Candida. Ann Intern Med. 2002;136: 834-44, http://dx.doi.org/10.7326/0003-4819-136-11-20020 6040-00013

11. Rafferty ME, McCormick MI, Bopp LH, Baltch AL, George M, Smith RP, et al. Vancomycin-resistant enterococci in stool specimens submitted for Clostridium difficile cytotoxin assay. Infect Control Hosp Epidemiol. 1997;18:342-4, http://dx.doi. org/10.1086/647623

12. Novak A, Spigaglia P, Barbanti F, Goic-Barisic I, Tonkic M. First clinical and microbiological characterization of Clostridium difficile infection in a Croatian University Hospital. Anaerobe. 2014;30:18-23, http://dx.doi.org/10.1016/j.anaerobe.2014.07.007

13. Alonso CD, Treadway SB, Hanna DB, Huff CA, Neofytos D, Carroll KC, et al. Epidemiology and outcomes of Clostridium difficile infections in hematopoietic stem cell transplant recipients. Clin Infect Dis. 2012;54:1053-63, http://dx.doi.org/ 10.1093/cid/cir1035

14. Leung S, Metzger BS, Currie BP. Incidence of Clostridium difficile infection in patients with acute leukemia and lymphoma after allogeneic hematopoietic stem cell transplantation. Infect Control Hosp Epidemiol. 2010;31:313-5, http://dx.doi.org/ $10.1086 / 651066$

15. Vehreschild MJ, Meissner AM, Cornely OA, Maschmeyer G, Neumann S, von Lilienfeld-Toal M, et al. Clinically defined chemotherapy-associated bowel syndrome predicts severe complications and death in cancer patients. Haematologica. 2011; 96:1855-60, http://dx.doi.org/10.3324/haematol.2011.049627

16. Cetinkaya Y, Falk P, Mayhall CG. Vancomycin-resistant enterococci. Clin Microbiol Rev. 2000;13:686-707, http://dx.doi. org/10.1128/cmr.13.4.686-707.2000

17. Debast SB, Bauer MO, Kujiper EJ, on behalf of the Committee. European Society of Clinical Microbiology and Infectious Diseases: update of the treatment guidance document for Clostridium difficile infection. Clin Microbiol Infect. 2014;20:1-26, http://dx.doi.org/10.1111/1469-0691.12418
18. Chlebicki MP, Ling ML, Koh TH, Hsu LY, Tan BH, How KB, et al. First outbreak of vancomycin-resistant Enterococcus faecium in a tertiary care hospital in Singapore. Infect Control Hosp Epidemiol. 2006;27:991-3, http://dx.doi.org/10.1086/507289

19. Murray BE. Vancomycin resistant enterococci. Am J Med. 1997;102:284-93, http://dx.doi.org/10.1016/S0002-9343(99) 80270-8

20. NNIS System. National Nosocomial Infections Surveillance (NNIS) system report, data summary from January 1992 through June 2004, issued October 2004. Am J Infect Control. 2004; 32:470-85, http://dx.doi.org/10.1016/S0196655304005425

21. Diaz Granados CA, Zimmer SM, Klein M, Jernigan JA. Comparison of mortality associated with vancomycin-resistant and vancomycin-susceptible enterococcal bloodstream infections: a meta-analysis. Clin Infect Dis. 2005;41:327-33, http://dx.doi. org/10.1086/430909

22. Carmeli Y, Eliopoulos G, Mozaffari E, Samore M. Health and economic outcomes of vancomycin-resistant enterococci. Arch Intern Med. 2002;162:2223-8, http://dx.doi.org/10.1001/ archinte.162.19.2223

23. Lam S, Singer C, Tucci V, Morthland VH, Pfaller MA, Isenberg HD. The challenge of vancomycin-resistant enterococci: a clinical and epidemiologic study. Am J Infect Control. 1995; 23:170-80, http://dx.doi.org/10.1016/0196-6553(95)90038-1

24. Wells CL, Juni BA, Cameron SB, Mason KR, Dunn DL, Ferierri $\mathrm{P}$, et al. Stool carriage, clinical isolation, and mortality during an outbreak of vancomycin-resistant enterococci in hospitalized medical and/or surgical patients. Clin Infect Dis. 1995;21:45-50, http://dx.doi.org/10.1093/clinids/21.1.45

25. Edmond MB, Ober JF, Weinbaum DL, Pfaller MA, Hwang T, Sanford MD, et al. Vancomycin-resistant Enterococcus faecium bacteremia: risk factors for infection. Clin Infect Dis. 1995; 20:1126-33, http://dx.doi.org/10.1093/clinids/20.5.1126

26. Papanicolau GA, Meyers BR, Meyers J, Mendelson MH, Lou $\mathrm{W}$, Emre S, et al. Nosocomial infections with vancomycin-resistant Enterococcus faecium in liver transplant recipients: risk factors for acquisition and mortality. Clin Infect Dis. 1996; 23:760-6, http://dx.doi.org/10.1093/clinids/23.4.760

27. Linden PK, Pasculle AW, Manez R, Kramer DJ, Fung JJ, Pinna $\mathrm{AD}$, et al. Differences in outcomes for patients with bacteremia due to vancomycin-resistant Enterococcus faecium or vancomycin-susceptible Enterococcus faecium. Clin Infect Dis. 1996; 22:663-70, http://dx.doi.org/10.1093/clinids/22.4.663

28. MacIntyre CR, Empson M, Boardman C, Sindhusake D, Lokan J, Brown GV. Risk factors for colonization with vancomycin-resistant enterococci in a Melbourne hospital. Infect Control Hosp Epidemiol. 2001;22:624-9, http://dx.doi.org/10. 1086/501833

29. Suntharam N, Lankford MG, Trick WE, Peterson LR, Noskin GA. Risk factors for acquisition of vancomycin-resistant enterococci among hematology-oncology patients. Diagn Microbiol Infect Dis. 2002;43:183-8, http://dx.doi.org/10.1016/ s0732-8893(02)00392-9 
30. Shay DK, Maloney SA, Montecalvo M, Banerjee S, Wormser GP, Arduino MJ, et al. Epidemiology and mortality risk of vancomycin-resistant enterococcal bloodstream infections. J Infect Dis. 1995;172:993-1000, http://dx.doi.org/10.1093/ infdis/172.4.993

31. Falk PS, Winnike J, Woodmansee C, Desai M, Mayhall CG. Outbreak of vancomycin-resistant enterococci in a burn unit. Infect Control Hosp Epidemiol. 2000;21:575-82, http://dx. doi.org/10.1086/501806

32. Montecalvo MA, de Lencastre H, Carraher M, Gedris C, Chung M, VanHorn K, et al. Natural history of colonization with vancomycin-resistant Enterococcus faecium. Infect Control Hosp Epidemiol. 1995;16:680-5, http://dx.doi.org/10.1086/ 647041

33. Poduval RD, Kamath RP, Corpuz M, Norkus EP, Pitchumoni CS. Clostridium difficile and vancomycin-resistant enterococcus: the new nosocomial alliance. Am J Gastroenterol. 2000;95:3513-5, http://dx.doi.org/10.1111/j.1572-0241. 2000.03291.x

34. Fujitani S, George WL, Morgan MA, Nichols S, Murthy AR. Implications for vancomycin-resistant Enterococcus colonization associated with Clostridium difficile infections. Am J Infect
Control. 2011;39:188-93, http://dx.doi.org/10.1016/j.ajic. 2010.10.024

35. Tay JK, Bodle EE, Fisher DA, Lin RV, Kumarasinghe G, Tambyah PA. Screening for vancomycin-resistant enterococci using stools sent for Clostridium difficile cytotoxin assay is effective: results of a survey of 300 patients in a large Singapore Teaching. Hospital. Ann Acad Med Singapore. 2007;36:926-9.

36. Werner G, Coque TM, Hammerum AM, Hope R, Hryniewicz W, Johnson A, et al. Emergence and spread of vancomycin resistance among enterococci in Europe. Euro Surveill. 2008;13. pii:19046.

37. Payer Pal M, Tambic Andrasevic A. Antibiotic consumption in Croatia. In: Tambic Andrasevic A, Tambic T, Katalinic-Jankovic V, Payer Pal M, Bukovski S, Butic I, Soprek S, editors. Antibiotic Resistance in Croatia 2013. Zagreb: Croatian Academy of Medical Science; 2014. p. 57-9.

38. Timmers GJ, van der Zwet WC, Simoons-Smit IM, Savelkoul $\mathrm{PH}$, Meester HH, Vandenbroucke-Grauls CM, et al. Outbreak of vancomycin-resistant Enterococcus faecium in a haematology unit: risk factor assessment and successful control of the epidemic. Br J Haematol. 2002;116:826-33, http://dx.doi.org/ 10.1046/j.0007-1048.2002.03339.x

Sažetak

\section{KOLONIZACIJA VANKOMICIN REZISTENTNOM BAKTERIJOM ENTEROCOCCUS FAECIUM I CLOSTRIDIUM DIFFICILE INFEKCIJA U HEMATOLOŠKE BOLESNICE}

\section{Goić-Barišić, M. Radić, A. Novak, Ž. Rubić, N. Boban, B. Lukšić i M. Tonkić}

Vankomicin-rezistentni enterokoki (VRE), naročito Enterococcus faecium, spadaju među najznačajnije bolničke patogene, pri čemu su naročito ugroženi bolesnici oslabljenog imunosnog statusa. Pritom je najčešća pojava asimptomatske kolonizacije probavnog sustava koja može ustrajati duže vremena i biti rezervoar za širenje VRE na ostale bolesnike. Donosimo prikaz slučaja bolesnice s dijagnozom akutne mijelomonocitne leukemije praćene aplazijom koštane srži nakon indukcijske terapije. Bolesnica je liječena antibioticima širokog spektra. Tijekom hospitalizacije u bolesnice se razvila infekcija bakterijom Clostridium difficile (CDI) uz dokazanu kolonizaciju sojem Enterococcus faecium rezistentnog na vankomicin tijekom terapije zbog CDI. Također su prikazani čimbenici rizika koji su u navedenom slučaju mogli poslužiti kao potencijalni okidač za razvoj rezistencije, s osobitim naglaskom na CDI. Rano otkrivanje kolonizacije ili infekcije navedenim sojevima je iznimno značajan čimbenik bolničkog programa za prevenciju širenja bolničkih infekcija. Mikrobiološki nadzor uzimanjem nadzornih kultura mora biti obvezni dio protokola pri hospitalizaciji takvih bolesnika.

Ključne riječi: Akutna mijelomonocitna leukemija; Clostridium difficile; Enterococcus faecium; Vankomicin-rezistentni enterokok 